\title{
ЦЕНТАР ЗА ВИЗАНТИЈСКО-СЛОВЕНСКЕ СТУДИЈЕ
}

У раду се представљају активности Центра за византијско-словенске студије од његовог оснивања 2015. године до данас, а такође се указује на значај овог центра за развој научне мисли посвећене византијско-словенским везама. Центар представља организациону јединицу Универзитета у Нишу, чији је управник и један од оснивача проф. др Драгиша Бојовић, редовни профеcop на Департману за србистику Филозофског факултета у Нишу. Центар је веома плодотворан на различитим пољима, чиме се афирмишу византијскословенске студије у земљи и иностранству. Веома је важна и чињеница да се многе активности овог и још два значајна нишка центра која су усмерена на црквене студије често прожимају, те се може говорити о њиховом суживоту и заједничкој мисији.

Кључне речи: Центар за византијско-словенске студије, Универзитет у Нишу, византијско-словенске студије, црквене студије.

1. Увод. Као једна од организационих јединица Универзитета у Нишу 2015. године основан је Центар за византијско-словенске студије (надаље Центар). Центар је основан са циљем, јасно изложеним у Одлуци о оснивању, ${ }^{3}$ да организује научна истраживања у различитим областима које за предмет имају византијску и словенску културу, уметност, историју, књижевност и сакралне језике, при чему је посебан акценат на византијском наслеђу у словенским земљама. Циљ Центра јесте повезивање истраживача у оквиру различитих научних пројеката на националном, регионалном и међународном нивоу.

Управник Центра за византијско-словенске студије и његов идејни творац јесте проф. др Драгиша Бојовић, редовни професор на Департману за србистику Филозофског факултета у Нишу, иначе управник и оснивач још

\footnotetext{
${ }^{1}$ jelena.stosic@filfak.ni.ac.rs.

${ }^{2}$ Рад је настао у оквиру интерног пројекта Србистика на Филозофском факултету у Нишу, Филозофског факултета у Нишу, чији је руководилац проф. др Надежда Јовић.

${ }^{3}$ Овај документ доступан је на следећем линку: https://www.ni.ac.rs/images/univerzitet/centriuniverziteta/Odluka_o_osnivanju_CVSS.pdf (19.3.2021).
} 
двају нишких центара - Центра за црквене студије ${ }^{4}$ и Међународног центра за православне студије. Заменик управника Центра је проф. др Бранко Горгијев, редовни професор Центра за стране језике Филозофског факултета у Нишу. О суживоту и нераскидивој вези поменута три центра говори у прилог велики број заједничких публикација, научних скупова и других активности које за циљ имају научна истраживања усмерена ка византијском црквеном наслеђу и српском средњем веку. Штавише, кроз активности Центра за црквене студије и Међународног центра за православне студије, како истиче И. Живковић, проф. др Драгиша Бојовић је „припремио атмосферу да до његовог формирања [формирања Центра, J. С.] дође” (Живковић 2020: 51).

Колегијум Центра чине наставници, сарадници и истраживачи Универзитета у Нишу, запослени на факултетима Универзитета у Нишу, као и студенти докторских студија који се баве византијско-словенским истраживањима. ${ }^{5}$

Активности Центра могу се пратити на страницама часописа Црквене cmyдије у рубрици под називом „Три центра између два броја”. Ова рубрика налази се на крају часописа и веома исрпно описује све што је претходне године урађено, што нам је било од велики помоћи при прикупљању података представљених у раду.

С обзиром на различите видове активности које су у претходних шест година организоване у оквиру рада Центра, надаље ће оне бити груписане ради боље прегледности на: научне скупове, издавачку делатност и остале активности.

2. НАучни скупови. Као пре свега научна институција, Центар организује научне скупове на којима окупља релевантне стручњаке из земље и иностранства, али и научни подмладак, што је одлична прилика за размену идеја и научних достигнућа.

2.1. Прве године битисања, непосредно након оснивања, Центар је организовао Међународну научну конференцију Византија и православље, која је одржана од 22. до 24. априла 2015. године. У оквиру ове научне конференције одржано је више научних предавања, као и изложба књига Ниш од црквених до византијско-словенских студија (в. Живковић 2020: 52).

2.3. Сада већ традиционално, Центар за византијско-словенске студије у сарадњи са остала два нишка центра организује научни скуп са међунаро-

\footnotetext{
${ }^{4}$ Ове године обележава се значајан јубилеј - 20-годишњица постојања Центра за црквене студије.

${ }^{5}$ Актуелни чланови Центра су: Драгиша Бојовић, Бранко Горгиев, Слађана Ристић Горгиев, Сунчица Денић, Ирена Љубомировић, Данијела Здравић Михаиловић, Славиша Недељковић, Владимир Алексић, Александар Ђорђевић, Мирко Станимировић, Јелена Стошић, Јасмина Шаранац Стаменковић, Кристина Митић, Анђелија Милић.
} 
дним учешћем под називом Византијско-словенска чтенија, ${ }^{6}$ на коме учествују еминентни стручњаци из земље и иностранства, али и научни подмладак. Први научни скуп (Византијско-словенска чтенија I) одржан је 25. новембра 2017. Византијско-словенска чтенија II одржана су 24. новембра 2018. године, а Византијско-словенска чтенија III 23. новембра 20019. године. Радни део скупа одржава се сваке године у просторијама Универзитета у Нишу и одвија се у више засебних сесија. ${ }^{7}$

2.4. Године 2017. Центар је организивао и научни скуп Српска краљевина у средњем веку у сарадњи са Филозофским факултетом у Београду, Филозофским факултетом у Новом Саду и Градом Краљевом, који је одржан од 15. до 17. септембра у Краљеву.

2.5. На Унверзитету у Нишу је 29. и 30. маја 2019. године одржан Други међународни конгрес православних научника у Србији „Образовање, наука, култура", у организацији Обједињења православних научника из Вороњежа и Центра. Суорганизатор је био Центар за византијско-словенске студије.

3. ИздАВАЧКА дЕЛАтност. Веома богата издавачка делатност Центра огледа се у великом броју публикација домаћих и страних аутора. Један део публикација издат је у сарадњи са неким од остала два нишка центра или неким другим образовним институцајама или институцијама културе. ${ }^{8}$

3.1. Центар је суиздавач научног часописа Црквене студије, који се налази на листи Министарства просвете, науке и технолошког развоја и носи категорију М24. Реч је о међународном часопису интердисциплинарног карактера, који је покренут 2004. године у издању Центра за црквене студије, а од 2015. године његов суиздавач, како је већ поменуто, постаје и Центар за византијско-словенске студије (Глишић 2019: 5, 7). ${ }^{9}$

\footnotetext{
${ }^{6}$ Зборник радова са Скупа носи категорију М33.

7 Године 2020. планирано је одржавање Византијско-словенских чтенија IV, али је због немогућности одржавања уживо отказан. Зборник радова је у припреми, тако да ће научна јавност бити у прилици да се упозна са радовима на пријављене теме. План и програм Чтенија може се пратити у поменутој рубрици на крају Црквених студија.

${ }^{8}$ Подаци о издањима трију центара могу се пратити на основу библиографије под називом Три иентра - једна мисија: библиограбија издать Центра за ирквене студије, Међународног центра за православне студије и Центра за византијско-словенске студије. Ова библиографија настала је као део испитних обавеза из предмета Библиотекарство и библиографија на докторским студијама Филолошког факултета Универзитета у Београду под менторством проф. др Александре Вранеш. Аутор библиографије је Теодора Бојовић, која нам је за потребе рада уступила рукопис пре објављивања, на чему јој овом приликом захваљујемо.

9 J. Глишић (2019) саставила је библиографију часописа Црквене студије, првих шеснаест бројева, који су изашли у седамнаест свезака. У међувремену је изашао и седамнаести број за 2020. годину, док је број за 2021. годину у припреми.
} 
3.2. Поред ове серијске публикације, дајемо списак осталих публикација чији је издавач или суиздавач био Центар. Наслови су поређани хронолошки: ${ }^{10}$

1. Тахиаос, Антоније-Емил Н. Солун и свет Словена: духовно и културно зрачење византијског града, 2014;

2. Дионисије Ареопагит. Дела, 2015;

3. Николић, Драган К. Закон судњи људем: најстарији словенски правни зборник, 2016;

4. Српска краљевства у средњем веку. Зборник радова, 2017;

5. Петровић, Александар М. Прва философија: темељни појмови философије према садржајима битија и јединство света историјске стварности, 2017;

6. Божидар Вуковић и српска књига у Венецији. Тематски блок из 15. броја часописа Црквене студије, 2018;

7. Византијско-словенска чтенија 1. Зборник радова, 2018;

8. Алексић, Владимир. Драгаши: прошлост, историја, предање, 2019;

9. Глишић, Јелена. Библиографија часописа „Црквене студије”, 2019;

10. Какридис, Јанис. Аргументащија код православних Словена у средњем веку: увод у проблематику, 2019;

11. Византијско-словенска чтенија 2. Зборник радова, 2019;

12. Мисао и мисија светог Јустина Поповића. Међународни тематски зборник, 2019;

13. Византијско-словенска чтенија 2. Зборник радова, 2020;

14. Турилов, Анатолиј. Источници српског средњег века, 2020;

На основу наведених издања може се приметити да поред часописа Црквене студије,$^{11}$ Центар учествује у издавању зборника са научних скупова, тематских зборника, превода, као и ауторских монографија. Број наведених публикација, укључујући и бројеве Црквених студија, показује нам да је издавачка делатност Центра веома плодна, као и да се велика пажња посвећује обележавању важних јубилеја. Поред домаћих аутора, присутни су и страни аутори, а преводи њихових књига чине страну литературу доступном домаћим научницима. Веома је важно истаћи да су издања трију нишких центара доступна у великом броју институција у земљи и иностранству.

\footnotetext{
${ }^{10}$ На списку су наведени аутори, наслови и година издања, односно називи зборника и година издања, док ће детаљни подаци бити доступни у библиографији коју је саставила Теодора Бојовић (в. фусноту 5).

${ }^{11}$ Шеснаести број овог часописа изашао је у две свеске, а посвећен је великом јубилеју, због чега носи назив Свети Сава и осам векова Српске иркве.
} 
4. ОстАЛЕ АКтивности. Иако су две најважније активности Центра научни скупови и издавачка делатност, постоји и низ других активности којима се такође афирмишу византијско-словенске студије.

4.1. Публикације Центра промовисане су на различитим институцијама у Нишу и земљи и иностранству, при чему су о њима говорили водећи стручњаци из различитих научних области. Тако су издања Центра промовисана у Бару, ${ }^{12}$ затим на промоцији издања нишких центара насловљених „У знаку великих јубилеја” на Међународном сајму књига у Београду 26. 10. 2018. године, на којој су говорили проф. др Синиша Мишић, проф. др Драгиша Бојовић и доц. др Кристина Митић. Том приликом промовисан је зборник Божидар Вуковић и српска књига у Венецији (поводом пет векова српске књиге у Венецији), као и тематски број Црквених студија посвећен Светом Сави (поводом осамсто година аутокефалности Српске православне цркве) и зборник Српска краљевства у средњем веку (поводом осам векова државности српске државе). Велики и значајан јубилеј аутокефалности Српске православне цркве обележен је свечаном академијом на Универзитету у Нишу 24. јануара 2019. године, ${ }^{13}$ када је представљен и број часописа Црквене студије који му је посвећен. Овај веома значајан број Црквених cmyдuja, пре свега због тематике којом се бави, али и због великог броја објављених радова, представљен је на Филозофском факултету у Косовској Митровици 12. марта 2019. године, у Музеју Херцеговине у Требињу 21. јуна 2019. године, када су представљени и зборници Божидар Вуковић и српска књига у Венецији и Српска краљевства у средњем веку, затим у оквиру Ћирилометодијевских сусрета, које је организовао Универзитет Ка' Фоскари у Венецијии од 19. до 21. септембра 2019. године, као и на Универзитету у Крагујевцу 15. октобра 2019. године и у Медија и реформ центру 1. октобра 2019. године.

4.2. Центар за византијско-словенске студије заједно са друга два нишка центра сваке године учествује са својим издањима на Светосавском сајму књига и на Међународном сајму књига, који се одржавају у Нишу, као самостални излагачи, док су на Сајму књига у Београду издања била изложена на штандовима Српске православне цркве, издавачке куће „Светигора” и Центра за промоцију науке (Боловић 2020а: 496). У оквиру Конгреса византолога одржаног у Београду од 22. 8. до 27. 8. 2016. године организован је сајам књига, на коме су представљене активности трију нишких центара,

\footnotetext{
${ }_{12}$ Тринаести број Црквених студија промовисан је у Бару у оквиру Међународног научног скупа о Светом Јовану Владимиру (17. септембра 2016. године) с обзиром на то да је овај број часописа посвећен овом светитељу. На промоцији су говорили блаженопочивши митрополит др Амфилохије, проф. др Александра Наумов и проф. др Драгиша Бојовић.

${ }^{13}$ Свечана академија одржана је и у Крипти Храма Светог Саве у Београду 11. маја 2019. године (в. Боловић 2020: 490).
} 
што је добар начин да се научна јавност упозна са њиховим делањем и прегалаштвом у очувању православља.

4.3. Центар је од 5. новембра до 17. децембра 2015. године организовао семинар под називом Византија и свет Словена. Предавања су организована сваке недеље у наведеном периоду, а предавачи су били са Правног факултета и Филозофског факултета Универзитета у Нишу и обухватили су различите аспекте византијског наслеђа у словенском свету.

4.4. Од 2016. године Центар је сваке академске године организовао у мају дводневну наставно-научну екскурзију за студенте Универзитета у Нишу у сарадњи са Департманом за српску и компаративну књижевност Филозофског факултета у Нишу. Ова екскурзија симболично носи назив „Пут светлости” јер је њен циљ да се студенти упознају са духовношћу и архитектуром српских манастира. Екскурзија је 2016. године обухватила посету Ђурђевим ступовима, Петровој цркви, Сопоћанима, Студеници, Жичи, Љубостињи и Лазарици. У Студеници је проф. др Драгиша Бојовић одржао предавање на тему Однос Светог Саве према ћутању и плачу. Екскурзија је прилика студентима који се баве српским средњим веком са различитих аспеката да осете дух средњовековља и православља који ови манастири и цркве чувају кроз векове. Године 2017. студенти су имали прилике да посете Милешеву, Сопоћане, Ђурђеве ступове, Студеницу, Жичу и Љубостињу. Овом приликом проф. др Драгиша Бојовић је у Пријепољу и Студеници одржао два предавања - Доментијанов опис преноса моштију Светога Саве и Стваралачки портрет краља Стефана Првовенчаног, која су била намењена студентима, али и осталим посетиоцима. Наредне године студенти су посетили Милешеву, Сопоћане, Ђурђеве ступове, Петрову цркву, Градац, Жичу, Студеницу и Љубостињу. Проф. др Драгиша Бојовић је овом приликом одржао предавање на тему Поуке Светога Саве.

4.5. Веома је важно истаћи да је Центар иницирао настанак Међународне научне мреже Рax Byzantino-Slava, чији је први председавајући био проф. др Драгиша Бојовић. Поред трију нишких центара, чији је допринос у оснивању ове мреже огроман, у његовом оснивању учествовале су и 22 институције из Србије, Грчке, Бугарске, Русије, Грузије, Пољске, Италије и Швајцарске. ${ }^{14}$ Током 2016. године одржане су две радне конференције Мреже. Прва је одржана у Нишу 31. октобра, а друга у Софији 26. новембра.

На крају мандата проф. др Драгише Бојовића као председавајућег Мрежи број институција које учествују у њеном раду повећао се на $30 .{ }^{15}$ За-

\footnotetext{
${ }^{14}$ Подаци преузети из документа са следећег линка: https://www.ni.ac.rs/images/univerzitet/ centri-univerziteta/MREZA_PAX_BYZANTINO-SLAVA-1.pdf (13.4.2021).

${ }^{15}$ О којим институцијама је реч в.: Бојовић 2018: 933.
} 
вршен је и пројекат стварања електронске библиотеке Pax Byzantino-Slava. ${ }^{16}$ Ова библиотека веома је значајан подухват јер се на једном месту могу наћи линкови до дигитализованих рукописа и књига, што је чини једном од највећих електронских библиотека ове врсте.

4.6. Центар има успостављену сарадњу са многим научним институцијама у земљи и свету. Године 2016. Центар је потписао уговор о сарадњи са Институтом за словенску филологију Јагелонског факултета у Кракову, а 2019. године о уговор о сарадњи са Обједињењем православних научника из Вороњежа (из Русије).

5. ЗАкљУчАк. На крају не смемо изоставити важну чињеницу - заједно са Центром за црквене студије и Међународним центром за православне студије Центар за византијско-словенске студије од свог оснивања учествује у очувању православне традиције на просторима Ниша, ширећи своје идеје и повезујући се са институцијама и научницима широм православног света. Заштитници Центра су Свети Ћирило и Методије, које његови чланови прослављају резањем колача 24. маја сваке године. У тексту о икони названој Сабор светих покровитеља и небеских заступника, ${ }^{17}$ на којој се налазе светитељи-заштитници трију центара, проф. др Драгиша Бојовић је, говорећи о заштитницима Центра за византијско-словенске студије, написао: „Јелини и Словени у сусрету правоверја, кроз ликове солунских апостола Ћирила и Методија" (2020б).

Многобројне активности Центра које су приказане у овом прегледу само потврђују констатацију да је основна особеност овог центра, као и осталих нишких центара, „континуитет остварених резултата” (Бојовић 2019).

\section{Литература}

Боловић, Драгиша. „Три центра између два броја”. Црквене студије XV (2018): 933-944.

Боловић, Драгиша. „Три центра између два броја”. Црквене студије XVI/2 (2019): 857-860.

Боловић, Драгиша. „Три центра између два броја”. Црквене студије XVII (2020): 473-497.

Боловић, Драгиша. „Прича о једној икони”. Православље, 1. јун 2020.

Боловић, Теодора. Три цеентра - једна библиографија. 2021 (у штампи).

\footnotetext{
${ }^{16}$ Библиотека се налази на адреси: paxbyzantinoslava.com (28. 4. 2021).

${ }^{17}$ Икону је према идеји проф. др Драгише Бојовића осликала Марија Ђинђић, иконописац.
} 
Глишић, Јелена. Библиографија часописа „Центар за ирквене студије”. Ниш: Центар за византијско-словенске студије - Центар за византијско-словенске студије Универзитета у Нишу - Међународни центар за православне студије, 2019.

Живковић, Ивица. Једина светлост која се није срела са тамом. Богословски допринос професора Драгише Бојовића. Ниш: Међународни центар за православне студије, 2020. 